\title{
A Study on Wear Characteristics of ADI Rotavator Blades
}

\author{
Mukesh Rana* \\ Department of Farm Machinery and Power Engineering, College of Technology, \\ GBPUAT, Pantnagar 263145 (Uttarakhand), India \\ *Corresponding author
}

\begin{tabular}{|c|c|}
\hline & A B S T R A C T \\
\hline & The experiment was conducted at G.B. Pant University of Agriculture \& Technology, \\
\hline Keywords & $\begin{array}{l}\text { Pantnagar. A rotavator is popularly used to reduce the amount of time and labour spent in } \\
\text { field preparation. However, wear of rotavator blades is very high, especially in sandy soil, }\end{array}$ \\
\hline ADI Blades, & which significantly affects its working life. This study was ADI rotavator blades compared \\
\hline $\begin{array}{l}\text { Rotavator, Tillage, } \\
\text { Field. Scanning }\end{array}$ & to indigenous and imported rotavator blades. The test result showed that average \\
\hline Electron & gravimetric wear rate of ADI and indigenous blades were $110.08,129.98,154.42$ and \\
\hline Microscope (SEM). & blades $\left(\mathrm{T}_{1}\right)$ at starting, bent and leg section were $0.36 \mathrm{~mm} / \mathrm{h}, 0.25 \mathrm{~mm} / \mathrm{h}$ and $0.025 \mathrm{~mm} / \mathrm{h}$ \\
\hline Article Info & than $\left(\mathrm{T}_{2}\right) 0.40 \mathrm{~mm} / \mathrm{h}, 0.27 \mathrm{~mm} / \mathrm{h}$ and $0.031 \mathrm{~mm} / \mathrm{h}$ and $\left(\mathrm{T}_{3}\right) 0.42 \mathrm{~mm} / \mathrm{h}, 0.27 \mathrm{~mm} / \mathrm{h}$ and \\
\hline $\begin{array}{l}\text { Accepted: } \\
29 \text { September } 2017 \\
\text { Available Online: } \\
10 \text { October } 2017\end{array}$ & $\begin{array}{l}0.18 \mathrm{~mm} / \mathrm{h} \text { and } 0.021 \mathrm{~mm} / \mathrm{h} \text { than } 0.26 \mathrm{~mm} / \mathrm{h}, 0.17 \mathrm{~mm} / \mathrm{h} \text { and } 0.016 \mathrm{~mm} / \mathrm{h} \text { respectively. The } \\
\text { wear rate of the ADI blades all treatments were significantly more than those of the } \\
\text { indigenous and imported blades, indicating a maximum wear loss. Therefore, it was } \\
\text { concluded that material composition of blades affects wear characteristics of both types of }\end{array}$ \\
\hline & blades. \\
\hline
\end{tabular}

\section{Introduction}

ADI (Austempered Ductile Iron) was invented in the 1950. But was commercialized and achived success only some year later. In ADI the metallurgical structure is manipulated through a sophisticated heat process. The "AUS" portion of the name refers to austenite. Austenite also known as Gamma phase iron $(\gamma-\mathrm{Fe})$ is a metallic nonmetallic allotrope of iron Austenite exists above the critical eutectoid temperature of $\left(726^{\circ} \mathrm{C}\right)$. It is named (Roberts-Austen).

Austempering is heat treatment that is applied to ferrous metals. Most notably steel and ductile iron. Benefits of the ADI components like decrease weight, cost, noise and increases of the strength properties. The use of rotavator is increasing due to its versatility in doing a good quality tillage job. However, in context with the Indian agriculture where tractors are mostly used in the power range of $35-55 \mathrm{hp}$ by a large number of farmers, it is essential that matching size rotavator is available for different power ranges of tractors. Rotavators are mostly available in the size of $1.20-1.80 \mathrm{~m}$ working width and which is suitable for tractors having $48 \mathrm{hp}$ and above. Generally, L-shaped blades are used in Indian rotavators. The work quality by using a rotavator not only depends on design 
parameters but rotor blade layout, speed of rotors, forward speed significantly affects the machine performance. When a tillage operation is performed in the field, the soil texture will be a function of soil conditions, blade kinematics and soil flow dynamics. It is recent years our country import rotavators blade, there are 14 leading manufacturers in India and around 50,000 units of rotavator are manufactured annually. A rotavator has a useful life of $2400 \mathrm{~h}$ (8 year) with annual use as 300 hours. The quality of material used for manufacturing of blades affects the wear; Yatsuk et al., (1971) reported too use of spring steel material for minimum wear of rotavator blades. Generally farmers used rotavators with the old worn out blades rather than replacing it i.e. these blunt rotavator blades require high draft and more energy.

However, limited studies on material composition, hardness and wear pattern of rotavator blades are available and these aspects are the most important for predicting service life of a blade. Therefore in view of preceding discussion, the present study was undertaken with object. Study on wear characteristics of selected rotavator blades type in actual field condition.

\section{Materials and Methods}

The present study was carried out to compare dimensional wear and material composition of ADI rotavator blades. The material composition and wear pattern of ADI blades and other Indigenous and Imported rotavator blades run for $100 \mathrm{~h}$ were determined, the weight loss and wear pattern of blades were also studied. ADI (Austempered Ductile Iron) blades were used for this study fabricated at Mechanical Engineering Research and Development Organization (MERADO) Durgapur, West Bengal. The Indigenous and Imported rotavator as well rotavator blades were available in local market.

\section{Experimental procedure of selected rotavator blades}

Surface characteristics of ADI, indigenous and imported rotavator blades were determined with the use of a Scanning Electron Microscope (SEM). Element analysis and imaging of ADI, indigenous and imported rotavator blades were performed. The (SEM) used in the study was equipped with an Energy Dispersive

\section{Spectrometer (EDS)}

In order to make the measurement, procedure was adopted as a sample blade having size $(60 \mathrm{~mm} \times 20 \mathrm{~mm} \times$ blade thickness $)$ was fitted in the specimen chamber and was mounted rigidly on a specimen holder called a specimen setup. The SEM has a provision to record automatically the surface morphology and elemental composition of mounted specimen in an attached computer. The surface morphology was obtained in the form of magnified image which shows different chemical composition around the surface of piece.

The experiment was carried by with three different make of blade considered as five treatments

The wear of rotavator blades was measured gravimetrically as well as dimensionally during the study. In gravimetric wear of rotavator blades, the weight loss of blade material was measured. Prior to starting experiment weight of all blades were taken on an Electronic balance (weighing capacity of $6000 \mathrm{~g}$ with least count of $1 \mathrm{~g}$ ) after each $25 \mathrm{~h}$ of working operation.

Dimensional wear was measured with respect to width and thickness. The length of blade was divided 12 divisions with two centimeters of each, and then the ordinary graph paper 
was pasted on inner side by aligning points of blades by forming a grid of $2 \mathrm{~cm} \times 2 \mathrm{~cm}$ fig. 3

The width was measured at each point along the length with the help of digital "Vernier Calliper" of least count $0.01 \mathrm{~mm}$. Starting from the outward point $\left(0^{\text {th }}\right.$ point $)$ of blade section, upto marked last point $\left(11^{\text {th }}\right.$ point $)$ on leg section the width was measured with "Digital Vernier Calliper (least count $0.01 \mathrm{~mm})$ ". The width was measured initially at all points and successive measurements were noted after 25, 50, 75, and $100 \mathrm{~h}$. The graphical representation of results showed the wear pattern. A deduction of $0.07 \mathrm{~mm}$ from Micrometer Screw gauge reading was made to compensate for graph paper thickness. The change in width of blades at different hours of operation has compared at 0th, 5th and 11th point along the length of blade and thickness at 0th, 6th, 9th and 11th point along the length with respect to width points.

\section{Results and Discussion}

Surface characteristics of new ADI blade, indigenous and imported rotavator blades were determined with the use of a scanning electron microscope (SEM). Element analysis and imaging of ADI, indigenous and imported rotavator blades were performed.

The elemental analysis of blades run for $100 \mathrm{~h}$ was determined along the blade sections (edge and middle portion). The composition and variation of elements along the blade portion is presented below.

It is observed that decrease in \% of Nickel made of ADI - II blades from 0.5 to $0.38 \% \mathrm{Ni}$ when as ADI-III blades was from 1 to $0.47 \%$ $\mathrm{Ni}$ in the edge of portion of both blades. The decrease in \% of nickel in ADI-III and ADI-II blades was due to wear-out of top layers on surface of blades after usage of $100 \mathrm{~h}$ working operations.
The wear loss in ADI treatments $\left(\mathrm{T}_{1}, \mathrm{~T}_{2}\right.$, and $\mathrm{T}_{3}$ ) was higher because of improper mixing of elements. The lower and higher value of nickel \% with respect to standard value of nickel $\%$ may be the reason of higher wear loss. The wear loss was obtained minimum in imported blades $\left(\mathrm{T}_{5}\right)$ due to the proper mixing and the amount of nickel \% (0.25 max) was standard (ISI 6690: 1981) with comparing to ADI and indigenous treatments. Dimensional wear with respect to width, thickness, and cutting edge thickness of ADI, Indigenous and Imported blades has been described in this section.

The average wear rate of width follows the same pattern as that of wear rate in weight at starting point of blade section after $100 \mathrm{~h}$ of working treatments $\mathrm{T}_{1}, \mathrm{~T}_{2}, \mathrm{~T}_{3}, \mathrm{~T}_{4}$, and $\mathrm{T}_{5}$ which were $0.36,0.40,0.42$, and $0.29 \mathrm{~mm} / \mathrm{h}$ equivalent to $138.22,152.44,158.71$ and 101.19 (\%), respectively, of the control treatment $\mathrm{T}_{5}(0.26 \mathrm{~mm} / \mathrm{h})$. Similarly, for middle point on bent section, the wear rates for $\mathrm{T}_{1}, \mathrm{~T}_{2}, \mathrm{~T}_{3}$, and $\mathrm{T}_{4}$ after $100 \mathrm{~h}$ of working were $0.25,0.27,0.29$, and $0.18 \mathrm{~mm} / \mathrm{h}$ whereas for end point of leg section were $0.025,0.031$, 0.037 , and $0.021 \mathrm{~mm} / \mathrm{h}$, respectively.

The rate of wear along width treatment $T_{5}$ was best followed by ADI, I, II, III, and Indigenous blades (Treatment) were in descending order, compared to control treatment $\left(\mathrm{T}_{5}\right)$.

The average wear loss in thickness decreases from points along width on blade section i.e. $(0,0)$ and $(0,3)$ points followed by bent section $(6,0)$ point leg section such as $(9,0)$ and $(11,0)$ points. The data of treatment $T_{2}$ and $T_{3}$ reveals that the wear loss on the cutting edge $\left(3^{\text {rd }}\right.$ and $6^{\text {th }}$ point along length of blade with respect to points along width) was more as compared to other leg points $\left(9^{\text {th }}\right.$ and $11^{\text {th }}$ point along length of blade with respect to points along width). 
Fig.1 Specification of ADI and imported rotavator blades

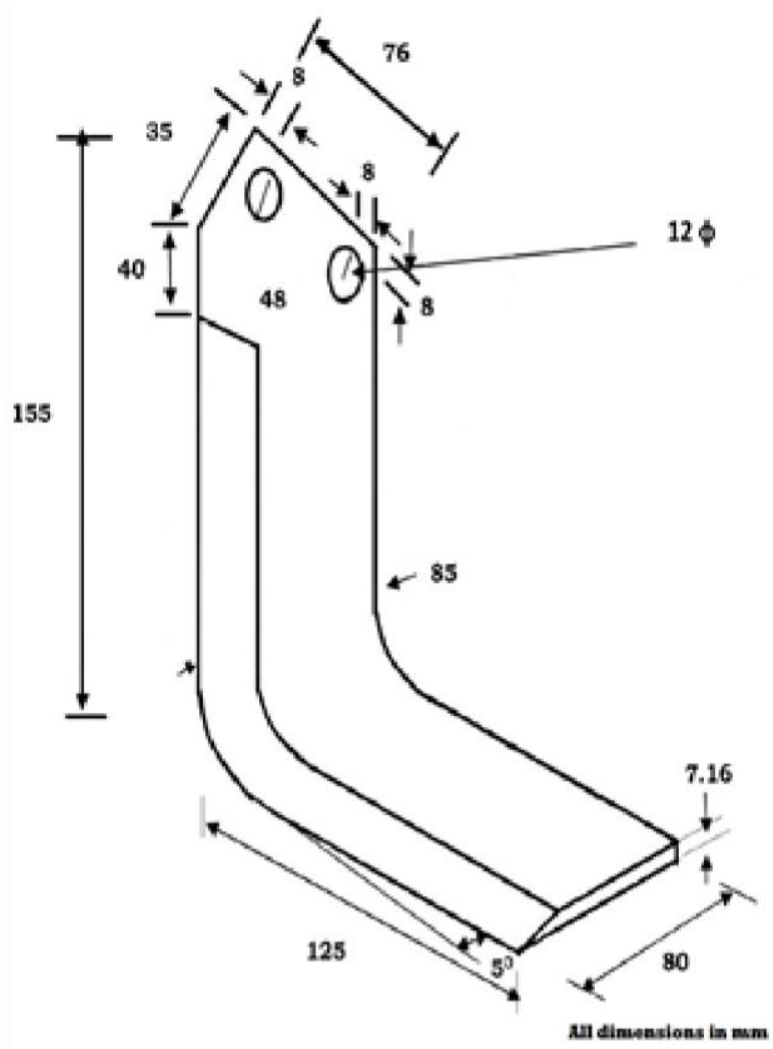

Fig.2 Size of blade sample for surface analysis with SEM

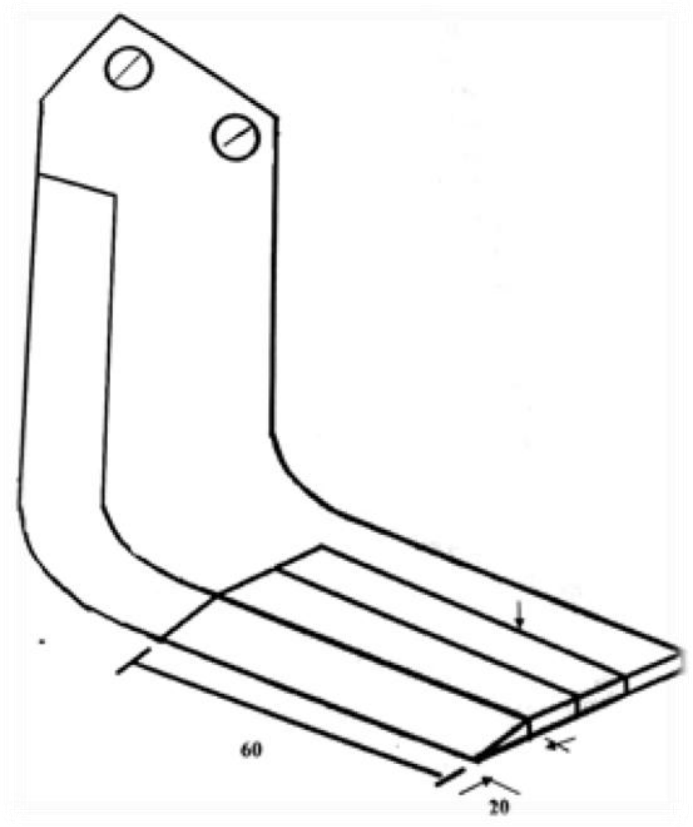


Fig.3 Grid points on surface of blade for width and thickness measurement

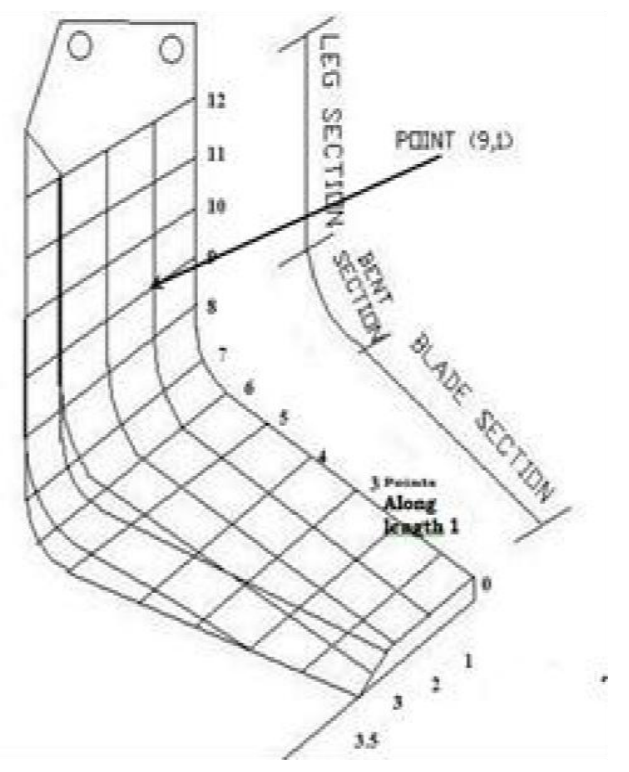

Fig.4 Cumulative reduction in blade width at 0th point in different treatment at different time interval

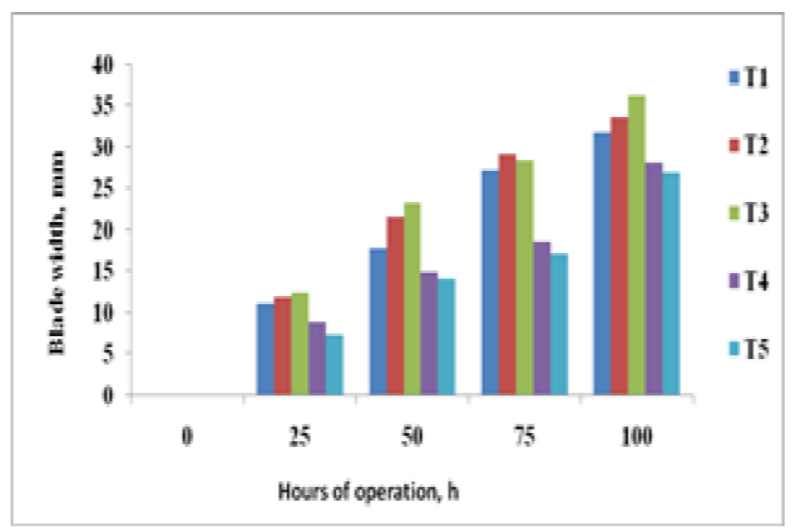

Fig.5 Cumulative reduction in blade width at 5th point in different treatment at different time interval

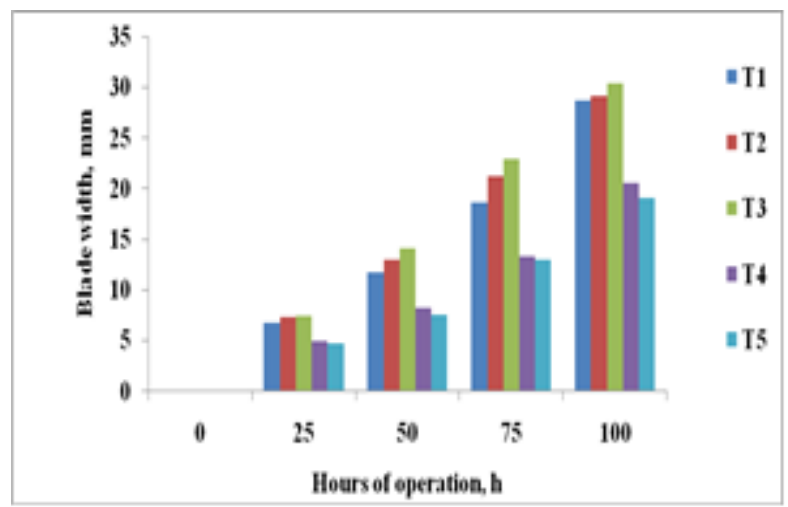


Fig.6 Cumulative reduction in blade width at 11th point in different treatment at Different time interval

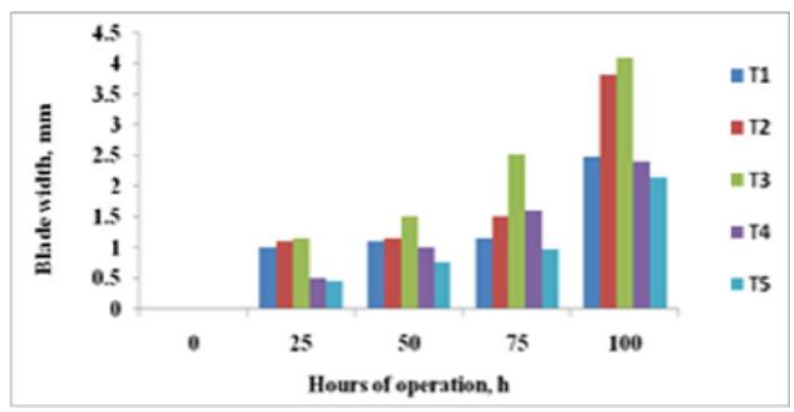

\begin{tabular}{|c|c|c|c|}
\hline Treatment & Type of blade & Mounting of blade & No. of replication \\
\hline $\mathrm{T}_{1}$ & ADI-I & \multirow{5}{*}{$\begin{array}{l}\text { Arranged in alternate } \\
\text { pattern on rotavator } \\
\text { flange mounted on } \\
\text { rotor shaft }\end{array}$} & 5 \\
\hline $\mathbf{T}_{2}$ & ADI-II & & 5 \\
\hline $\mathbf{T}_{3}$ & ADI-III & & 5 \\
\hline $\mathbf{T}_{4}$ & INDIGENOUS(ATI) & & 5 \\
\hline $\mathbf{T}_{\mathbf{5}}$ & IMPORTED & & 5 \\
\hline
\end{tabular}

In treatment $T_{5}$ the cutting edge thickness varied on $0^{\text {th }}, 5^{\text {th }}$ and $11^{\text {th }}$ point lines along length of blade with working periods. The variation in cutting edge at the above points range between $2.2-2.37 \mathrm{~mm}\left(0^{\text {th }}\right.$ point $), 2.5-2.72 \mathrm{~mm}\left(5^{\text {th }}\right.$ point), and $1.74-1.82 \mathrm{~mm}\left(11^{\text {th }}\right.$ point $)$ after 0 to $100 \mathrm{~h}$ whereas for all remaining points. The cutting edge at all the above mentioned points in treatment $T_{5}$ having more thickness as compared to other points, due to strength of material of blade section.

The surface characteristics of selected rotavator blades revealed that the chemical composition of blades varied with working hours. The maximum variation was found in $\operatorname{ADI}-\mathrm{III}\left(\mathrm{T}_{3}\right)$, $\operatorname{ADI}-\mathrm{II}\left(\mathrm{T}_{2}\right)$, and $\mathrm{ADI}-\mathrm{I}\left(\mathrm{T}_{1}\right)$ followed by indigenous $\left(\mathrm{T}_{4}\right)$ and imported blades.

It was also evident from chemical analysis that the variation in percentage of elements with working hours was effects on wear characteristics of blades.

The width of worn-out rotavator blades decreased with different working hours. The reduction in width being more on blade section, followed by bent and leg section. The thickness of rotavator blades decreased from blade section to leg section. The cutting edge thickness varied in all treatments has been in range of 0.73-3.95 $\mathrm{mm}$ after $100 \mathrm{~h}$ of working

It is observed that decrease in $\%$ of Nickel made of ADI - II blades from 0.5 to $0.38 \% \mathrm{Ni}$ when as ADI-III blades was from 1 to $0.47 \% \mathrm{Ni}$ in the edge of portion of both blades. The decrease in \% of nickel in ADI-III and ADI-II blades was due to wear-out of top layers on surface of blades after usage of $100 \mathrm{~h}$ working operations. The wear losses in ADI treatments $\left(\mathrm{T}_{1}, \mathrm{~T}_{2}\right.$, and $\mathrm{T}_{3}$ ) were higher because of uneven $\%$ of nickel (Ni) and improper mixing. The lower and higher value of nickel $(\mathrm{Ni}) \%$ with respect to standard value of nickel $(\mathrm{Ni}) \%$ may be the reason of higher wear loss. The wear loss was obtained minimum in imported blades of control treatment $\left(\mathrm{T}_{5}\right)$ due to the proper mixing and the amount of nickel (Ni) \% (0.25 max) as standard (ISI 6690: 1981) with comparing to $\mathrm{ADI}$ and indigenous treatments.

\section{Acknowledgement}

I take this golden opportunity to express my heartfelt and deepest sense of gratitude to those who have helped me to complete this 
manuscript. My debt many individuals can warmly be acknowledged but never full recompensed.

In the ecstasy of delight, I fumble for the words to pen down heartfelt veneration towards my mentor, erudite and revered teacher and elite guide, motive force and path director Dr. R.N. Pateriya Associate professor, Department of Farm Machinery and Power Engineering Chairman of my Advisory Committee for this unimpeachable incessant efforts planning and execution, valuable guidance through the course of investigation, parental care and painstaking rendered to me which helped me in bringing my surmount task to success. I express my cordial thanks to all employees of Department of Farm Machinery and Power, who helped me directly or indirectly during the course of present work, which will always rest with core of my heart.

\section{References}

Ahmet Celi, A., Celik, I. Ozturk and T. R. Way, 2008. "A Theoretical Approach for Determining the Irregularity of Soil Tillage Depth Caused by Horizontal Axis Rotary Tillers". Agricultural Engineering International: the CIGR Ejournal. Manuscript PM 08 003. Vol. X.

Cakmak, B., E. Aykas, i. Onal and e. Cakir, 2010. The performance of developed rotary tiller fitted with pneumatic seeder. Bulgarian journal of agricultural science, 16 (no 6): 801-810.

Deshmukh, and Singh, M.P. 2000, Studies on wear pattern of local and

Guskov, V. V., 1968. Effect of forward speed on the drawbar performance of a tracklaying tractor. J. Agric. Engg., 13, (3): 203209.

Imported L-shaped blade of rotavator. M.Tech.
Thesis, G.B. Pant University of Agriculture and Technology, pantnagar

Kurchania, A.K., 1997. Abrasive wear of cultivator shovels as affected by soil, tool and operating parameters. Thesis, M.Tech, G.B.P.U.A.T., pantnagar (U.K.)

Kushwaha, R.L., and Hua, P. 1992. Wear characteristics of regular and hard surfaced of cultivators' sweeps.

Kushwaha, R.L., and Shi, J. 1991 Investigation of wear of agricultural tillage tools. J.STLE, 47(3): 219-22.

Moore, M.A., 1975. The abrasive wear resistance of surface coating. J. Agric. Engg., 20: 167-170.

Reed, I. F., and Gordan, E. D. 1951. Determining the relative wear resistance of metals. J. Agric. Engg., (32): 92-103.

Reed, I. F., and McCreary, W. F. 1954. Effect of methods of manufacture and steel specification on the service of discs. J. Agric. Engg., (35): 91-97.

Richardson, R.C.D., 1967(b). The wear of metallic materials by soil practical Phenomenon. J. Agric. Engg. 12 (1): 2239.

Seth, G. S., and Ghosh, A. 1984. System approach to applied machinery management for growing wheat crop under paddy wheat crop rotation. Thesis, B. Tech. G. B. Pant University of Agriculture \& Technology, Pantnagar.

Sharda, A., and Dr S Singh, 2004. Effect of Selected Parameters on Field Performance of Rotary Tiller. IE (I) Journal.AG, Vol. 85.

Singh, C.P., 1972. High stress abrasions wear effect of load and speed. J. Agric. Engg., ISAE, 9(2): 14-21.

Zhang, J., and Kushwaha, R. L. 1999. Wear and draft of cultivator sweeps with hardened edges. J. Canadian Agricultural Engineering. 37 (1): 41-47.

\section{How to cite this article:}

Mukesh Rana. 2017. A Study on Wear Characteristics of ADI Rotavator Blades. Int.J.Curr.Microbiol.App.Sci. 6(10): 4880-4886. doi: https://doi.org/10.20546/ijcmas.2017.610.457 